\title{
An Integrated Multilayer Approach for Environmental Impact Analysis of Large Scale Infrastructure Projects (The Case of Tehran-North Freeway, Iran)
}

\author{
By Behzad Malekpour Asl , Peyman Khodabakhsh', \\ \& Hamid Fathi ${ }^{*}$
}

\begin{abstract}
This paper attempts to examine spatial strategic planning in terms of the regional economic development of Tehran-North freeway project. The paper introduces an integrated method to compile and prioritize strategies in order to optimize the environmental impacts of such projects and then develops and tests the model with data for the specific regions. This proposed methodological approach combined with strategic planning could be used to control and reduce the environmental impacts in the south, central and north Alborz Mountains as part of the project. The main result of this paper in to provide amendment strategies for areas with greatest environmental vulnerability and sustainability as a critical driving force for achieving increased regional development and thus the tailoring of polices to support regional economic development and growth.
\end{abstract}

Keywords: Environmental impact assessment, Infrastructure projects, Strategic planning, Tehran-North freeway.

\section{Introduction}

The concept of strategic planning giving structure to regional economic development had tended to be ignored traditionally by planners and economists who recognized only the significance of mega - project at the national level without attention to environmental or social impacts (Sharifzadegan et al. 2015). Any infrastructure or large-scale project will likely have different impacts on the surrounding environment both in a negative and positive ways. One of the typical kind of large scale infrastructural projects are transport infrastructure development projects with a great impact on the quality of the regional development. Moreover, strategic planning is a kind of planning that defines and compiles strategies in different scales more specifically in regional level. It is basically a process of mid and long term harmonization of the internal and external opportunities and resources around organizational goals. Strategic planning was initiated in 1950s and became commonly used in the 1960s and 1970s and has become more widespread in the 1980s and 1990s. Today, it is used in urban and regional planning by most city authorities and development organizations. Researchers have proposed very diverse and different methods for guiding strategic planning but they usually apply SWOT matrix as a common method for guiding the

\footnotetext{
*Assistant Professor, Shahid Beheshti University, Iran.

${ }^{\dagger}$ Ph.D. on Urban and Regional Planning, Berlin Institute of Technology, Germany.

${ }^{\star}$ M.A. on Urban and Regional Planning, University of Shahid Beheshti, Iran.
} 
strategic planning research (Hill 1995, David 2001).

The purpose of this paper is to present an integrated method for compiling and prioritizing strategies by integrating the Delphi, AHP, SWOT and QSPM techniques. Demonstration of this integrated methodology is applied in an effort to control and reduce the impacts of the construction of Tehran-North freeway on its surrounding environment in the south, central and north Alborz Mountains zones, which is located across the freeway from Tehran to the North.

Tehran-North freeway is one of the most important infrastructural transportation projects in Iran, with great environmental, economic, social, physical and transportation development potentials. The freeway starts in the Kan region in Tehran province and ends in the Chalous region in Mazandaran province with $120 \mathrm{~km}$ length (Road and Urbanization Ministry 2014). The project aims to provide a safe and high-speed transport connection between the north and central parts of Iran, while also facilitating connections with the neighboring countries to the north.

Early studies on the Tehran-North freeway project began in 1974 and after the Islamic Republic Revolution of Iran in 1979, studies on the freeway were put on ice by the Road and Urbanization Ministry. Later in 1984, Islamic Revolution Mostazafan Foundation assured to take over the responsibility for construction of the Tehran-North freeway and finally in 1987, Tehran-North Freeway Company was established with the mission to prepare a detailed study and design for the freeway. Against this background several consulting engineers were asked to develop strategic planning studies of Tehran-North freeway since 2006. This article is part of the studies, which were carried out by the authors of this paper between the years 2011 to 2013 and eventually approved by the High Council of Architecture and Urban Planning of Iran (The Ministry of Road and Urbanization in 2014).

\section{Strategic Planning: Neglected Way of Planning in Iran}

In the literature of planning theories, there exist two origins for the concept of "strategy". The Latin word "Stratum", meaning the way for movement, and the Greek word "Strategos" having a general and overall meaning. The terminology "strategy" was for the first time identified in the late $19^{\text {th }}$ century as the importance of war tactics grew and especially in the military context.

Today the concept is used in many fields, including political, economic planning and especially management. The strategic planning routes in the field of management were used as a general scheme that serves as an overall plan for facilitation of efficient management for achieving the overall organizational objectives. To this sense, concepts such as mission, vision, goals and objectives fall within the framework of strategic planning (Kazaz and Ulubeyli 2009).

In Iran, as a developing country, it is more than 50 years that comprehensive plans are applied in diverse scales of urban and regional development. Such a planning methodology has not been capable of solving complex urban issues. The complexity of urban problems in post industrialized developed states, especially in 
late 1960s, and the constant changes of urban issues during the more than 20 years after the World War II both in political and economic attitudes as well as criticisms to the traditional approaches of planning in the second half of 1960s naturally resulted in changes and general views on planning, especially urban planning. Moreover, the impacts of other disciplines such as sociology on planning helped to identify the shortcomings of the traditional methods of physical planning and orientation of customary planning from comprehensive to systematic ones.

The systematic ideology on planning is in contrast with the traditional approach (i.e. comprehensive ideology) as a static approach to devising planning policies. The traditional approach has always introduced a comprehensive and broad rational theory on planning and stressed on the possibility of reviewing and monitoring the planning procedure. This will eventually lead to manifestation and acceptance of the ideology of spatial planning (meaning attention to the social, economic, political, organizational and managerial aspects along with the physical aspects of planning) and strategic planning.

This simplistic attitude of planners in urban development to change political and social procedures instead of giving attention to public interests and providing freedom were amongst the elements of traditional methods that were questioned and criticized by the new and emerging approach called strategic planning (Mintzberg 1994, Price and Newson 2003).

The proponents of strategic planning assert that this kind of planning not only creates guidelines for local development but also brings about coordination among different sectors on the scale and location of future development in regional levels and creates intra-sectional correspondence (for instance between application of land, housing, transportation, education, facilities, economic development and other activities). So, on the one hand, strategic planning attaches essential importance to development management and consequently, it pays attention to local management. On the other hand, it is closely related with spatial planning due to the fact that it acts within the framework of geographical space, which is an output of a synthesis of physical, economic and social factors in a certain location. Yet, we believe that another outstanding characteristic of strategic planning is that it does not act on certainty when forecasting or predicting; rather, it is always faithful to the laws of non-absoluteness of phenomenon in development.

As for methodology, it should be said that one of the most important concepts in strategic planning is the strategic ideology, which enables one to turn mental issues into real ones. Meanwhile, it should be possible to bring about realistic outcomes out of mental thoughts and reach long-term, general and influential prospects and views through passing from unknown and unpredictable factors. It should not suffice merely to provide details of the present; rather, it should also focus on major factors affecting the future. Therefore, if there have been three basic phases of planning namely; "current conditions", "analysis" and "prediction" important in the traditional method of planning, there should be at least four more phases in strategic planning alongside the phases on the basis of planning procedure and the characteristics of planning and strategic ideology accordingly. These additional phases are: 
- Determining specific goals of the subject under planning

- Making alternatives and their assessment

- Implementing and setting strategies

- Implementing plans, monitoring and revising them

In this context, strategic thought serves as the first step in the strategic planning procedure both in developing and developed territories (Mintzberg 1994, Porter 1987).

\section{Study Methods}

The research methodology is elaborated on a combination of qualitative and qualitative methods. This includes an integrated method comprised of the SWOT, QSMP and AHP models with the aim of mitigating the environmental impact of large scale infrastructural projects.

\section{SWOT Matrix}

The SWOT matrix is a helpful method for analyzing an urban system. With SWOT the effects of creating a project can be analyzed, which might not have been part of what the analysis was commissioned for due to internal and external factors (Talaei et al. 2009, Kandakoglu 2009, Podvezko et al. 2010).

The SWOT matrix comprises four main factors, including strengths and weaknesses (internal elements) and opportunities and threats (external factors). The comparison of the Strengths and Opportunities results in the StrengthOpportunity ( $\mathrm{SO}$ ) assessment. Also comparison of the strengths and threats produces the Strengths-Threats (ST) opportunities assessment. Moreover, comparison of the weaknesses and Opportunities will yield Weakness-Opportunity (WO) strategies and comparisons of Weaknesses and Threats would result in Weaknesses-Threats (WT) strategies. Eventually, by using a SWOT matrix, one can develop different strategies, which can be prioritized according to their relative importance (Chang and Huang 2006). Moreover, the SWOT method is used in defining key internal and external elements, which are important in helping an organization meeting its goals (Houben et al. 1999). In addition, the internal and external factors derived from SWOT analysis help identify strategic factors. The SWOT method compiles strategies based on the strengths and weaknesses as well as opportunities and threats (Kandakoglu et al. 2009). Moreover, SWOT promotes strengths and opportunities while minimizing the threats and weaknesses, and changing weaknesses into strengths so that while pursuing opportunities one can minimize internal weaknesses and external threats (Chang and Huang 2006, Amin et al. 2011). 
QSPM Model

The "strategies definition" state could be subdivided into the following three stages:

- Stage 1, "input stage": preparation of input information based on the external and internal factors.

- Stage 2, "matching stage" : generation of alternative strategies

- Stage 3, "decision stage": integration of the quantitative strategic planning matrix (QSPM). Together with SWOT matrix, this model would be used to determine the degree of attraction of the compiled strategies. Using this model, one can identify objectively different high potential strategies (David 1983).

In other words, the strategies revealed by the SWOT matrix are prioritized by QSPM in order to select those strategies that are more reliable and achievable (David 2001).

\section{Delphi Technique}

Dalkey (1969) and his associates originally developed the Delphi technique in the 1950s. This method aims to gain access to mental and cognitive convergence in the thinking of specialists and experts in different dimensions. Basically, structures of the Delphi method focus on a complex problem so that, over several iterations, a team or group can find an agreement about a future matter (Hasson et al. 2000). This method has several primary characteristics as below:

- Problem definition

- An expert panel that represents a broad opinion on the subject being examined. These experts are usually anonymous.

- The researcher constructs a series of questionnaires.

- An iterative process contains three to four iterations of questionnaires and feedback reports.

Although three to four iterations are normally used, iterations should be stopped when convergence is achieved. At the end, the researcher should apply a final report and shares it with the Delphi team for final edits and comments (Hasson et al. 2000).

\section{Analytical Hierarchy Process (AHP)}

The AHP model was developed by Saaty TL in 1970s. This model is based on three levels. The first level addresses model structure issues by collecting the objectives, indices and alternatives. The second level is to compare indices and alternatives and the third level is to prioritize the indices and choices. The AHP model has diverse applications in solving complicated issues in the decision 
making process (Kurttila et al. 2000, Albayrak and Erensal 2004, Lee et al. 2011). In the AHP model a one by one comparison judgments are made to determine the correlation of importance among indices and sub-indices. The basis of judgment for the comparative judgments is addressed in Table 1.

Table 1. Interpretation of Entries in a Pairwise Comparison Matrix

\begin{tabular}{|l|l|}
\hline $\begin{array}{l}\text { Value of } \\
\text { aij }\end{array}$ & \multicolumn{1}{c|}{ Interpretaion } \\
\hline $\mathbf{1}$ & Objectives $\mathrm{i}$ and $\mathrm{j}$ are equal of importance \\
\hline $\mathbf{3}$ & Objective $\mathrm{i}$ is weakly more important than objective $\mathrm{j}$ \\
\hline $\mathbf{5}$ & $\begin{array}{l}\text { Experience and judjment indicate that objectiv } \mathrm{i} \text { is strongly more important } \\
\text { than objective } \mathrm{j}\end{array}$ \\
\hline $\mathbf{7}$ & Objective $\mathrm{i}$ is very strongly or demonstrably more important that objetive $\mathrm{j}$ \\
\hline $\mathbf{9}$ & Objective $\mathrm{i}$ is absolutely more important that objective $\mathrm{j}$ \\
\hline $\mathbf{2 - 4 - 6 - 8}$ & $\begin{array}{l}\text { Intermedite values-for example, a value of } 8 \text { means that objective } \mathrm{i} \text { is midway } \\
\text { between strongly and absolutely more important than objective } \mathrm{j}\end{array}$ \\
\hline
\end{tabular}

Source: Saaty 1980.

In the third level of AHP model, the correlation of importance of choices is determined. In this phase, the priority of the options in connection with each of the sub-indices, if any, is judged otherwise, the connection is determined directly with the indices themselves. At the end, the final score of options is determined. In this phase, the final importance score of each option is determined. To this end, the principle of hierarchic composition leads to a Priority Vector (PV) by taking all judgments in all hierarchical levels into consideration.

Using the AHP model requires the direct participation of the decision makers who are best informed to make two-by-two comparison of indices in relation to each other. In this process, using other models of polling in composition with the AHP model can be helpful. Furthermore, using the AHP model can be helpful in case that goals of assessment are clear and the criteria are determined as well as the options of comparison are taken into consideration (Handfield el al. 2002).

\section{Methodology of the Proposed Model}

In this article, we propose an integrated model by combining the DelphiAHP-SWOT-QSPM for strategic planning purposes. Using this integrated model helps to understand the current situation better and to compile and prioritize the strategies with more accuracy and adjustment. This integrated model is used for the evaluation of trio Alborz zones vulnerability in order to identify and prioritize the best strategies for monitoring and reducing impacts of the Tehran- North freeway construction.

To do so, as an integrated process, the current situation is studied and described to the Delphi team in several workshops (incl. video conference or through email). Second, a variety of indices are selected for assessment based on the planning objectives. These indices are prioritized by the Delphi team. Third, 
initial indices are examined again by the AHP model and the hierarchies of alternatives are determined compared to each other. The applied AHP method in this article aims to identify that 'Which of trio zones of Alborz Mountains are more vulnerable to Tehran-North freeway construction?'. Thus the trio zones of Alborz are defined as AHP study areas.

In the next step, the SWOT method is applied to analyze the current situation through identification of strengths and weaknesses (the internal factors) and the opportunities and threats (the external factors) and to compile the strategies. Finally, the best strategies are prioritized by using the QSPM method.

The combination of Delphi and AHP methods in this paper helps to improve the reliability and validity of measures. The reliability of measures in the Delphi method differs from one panel to another and the results in the final round of judgments might be due more to some pressure. Furthermore, the composition of the Delphi method, the AHP model and the SWOT and QSPM matrix, used in this article, helps to bring conformity across all points of view, bringing further consensus on the goals. Figure 1 shows the structure of the proposed model.

Figure 1. Structure of Proposed Model

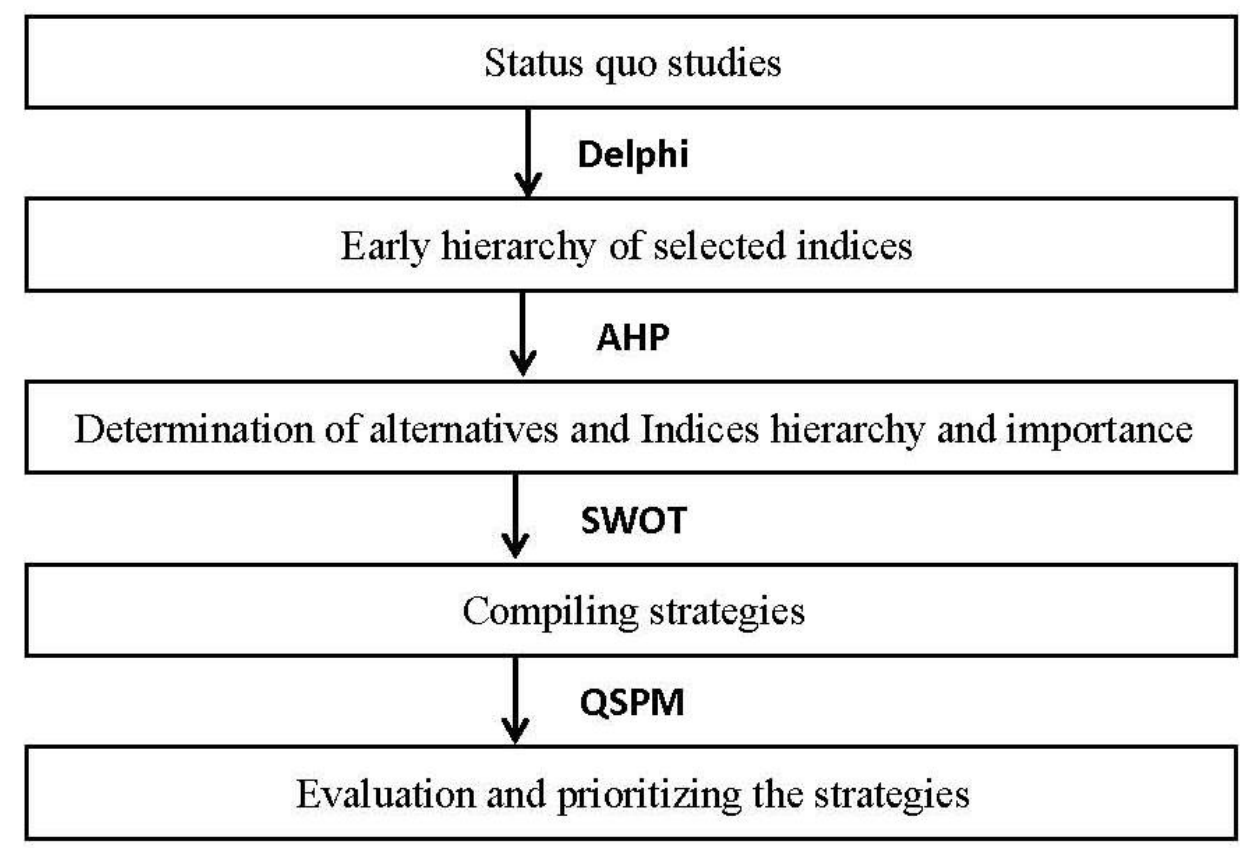

Implementation of Proposed Model

Interview of Delphi Team and Identification of Indicators

During May and December 2006, a group of experts including 40 experts were selected as the Delphi team. They were put into three economic, environmental as well as transportation groups and were asked to specify the strengths, weaknesses, opportunities and threats of the freeway in each of the 
above mentioned dimensions. The team of experts and researchers then extracted various indices to evaluate impacts of the freeway on the surrounding environment. Using the Delphi method, the experts were asked to determine the importance of those groups of indices with respect to the issue under study. Before starting the Delphi procedure, the authors presented necessary guidelines about the freeway project in several workshops. The working groups helped bringing about convergence and solidarity among directors, experts and authors so that all participants became acquainted with the issue closely.

Before starting the rounds of the Delphi method, the authors selected seven indices that were considered important to achieving the objectives of the project including: (A) soil and capability of lands, (B) plant and animal ecology, (C) climate, (D) geology, (E) risk of tremors, (F) topography and (G) construction. Following this, a questionnaire was created based on the chosen indices.

At the first round, the Delphi team was asked to determine priorities in accordance to the objectives. At the second round, the collected responses were summarized by the authors of this paper. Next the summary results were sent back to the Delphi team to review and resubmit their opinions. At the third and final round, an early hierarchy of importance of the selected indices was determined by aggregating the ratings (Table 2).

Table 2. Early Hierarchy of Selected Indices by Delphi Technique

\begin{tabular}{|l|c|}
\hline Indices & Early Hierarchy of Selected Indices \\
\hline Soil and capability of lands & $\mathbf{2}$ \\
\hline Plant and animal ecology & $\mathbf{1}$ \\
\hline Climate & $\mathbf{4}$ \\
\hline Geology & $\mathbf{7}$ \\
\hline Risk of tremors & $\mathbf{6}$ \\
\hline Topography and steepness & $\mathbf{5}$ \\
\hline Construction & $\mathbf{3}$ \\
\hline
\end{tabular}

Determining Final Correlation of Indices

Table 3. The Matrix of Two-By-Two Comparison of Indices in Three South, Central, North Alborz, Zones

$\left[\begin{array}{cccccccc} & A & B & C & D & E & F & G \\ A & 1 & 1 / 2 & 3 & 7 & 5 & 4 & 2 \\ B & 2 & 1 & 4 & 8 & 7 & 5 & 3 \\ C & 1 / 3 & 1 / 4 & 1 & 4 & 3 & 2 & 1 / 2 \\ D & 1 / 7 & 1 / 8 & 1 / 4 & 1 & 1 / 2 & 1 / 3 & 1 / 5 \\ E & 1 / 5 & 1 / 7 & 1 / 3 & 2 & 1 & 1 / 2 & 1 / 4 \\ F & 1 / 4 & 1 / 5 & 1 / 2 & 3 & 2 & 1 & 1 / 3 \\ G & 1 / 2 & 1 / 3 & 2 & 5 & 4 & 3 & 1\end{array}\right]$

$\mathrm{A}=\sqrt[7]{1 / 2 \times 1 \times 7 \times 5 \times 4 \times 3 \times 2}=2.37$

$\mathrm{B}=\sqrt[7]{2 \times 1 \times 4 \times 8 \times 7 \times 5 \times 3}=2.88$ 


$$
\begin{aligned}
& \mathrm{C}=\sqrt[7]{1 / 3 \times 1 / 4 \times 1 \times 4 \times 3 \times 1 / 2}=1 \\
& \mathrm{D}=\sqrt[7]{1 / 7 \times 1 / 8 \times 1 / 4 \times 1 \times 1 / 2 \times 1 / 3 \times 1 / 5}=0.28 \\
& \mathrm{E}=\sqrt[7]{1 / 7 \times 1 / 5 \times 1 / 3 \times 2 \times 1 \times 1 / 2 \times 1 / 4}=0.42 \\
& \mathrm{~F}=\sqrt[7]{1 / 4 \times 1 / 5 \times 1 \times 2 \times 3 \times 1 / 2 \times 1 / 3}=.65 \\
& \mathrm{G}=\sqrt[7]{1 / 2 \times 1 / 3 \times 2 \times 4 \times 5 \times 3 \times 1}=1.53 \\
& \mathrm{~W}_{\mathrm{A}}=\frac{2.37}{9.15}=.25 \\
& \mathrm{~W}_{\mathrm{B}}=\frac{2.88}{9.15}=.31 \\
& \mathrm{~W}_{\mathrm{C}}=\frac{1}{9.15}=.10 \\
& \mathrm{~W}_{\mathrm{D}}=\frac{0.28}{9.15}=.03 \\
& \mathrm{~W}_{\mathrm{E}}=\frac{0.42}{9.15}=.04 \\
& \mathrm{~W}_{\mathrm{F}}=\frac{0.65}{9.15}=.07 \\
& \mathrm{~W}_{\mathrm{G}}=\frac{1.53}{9.15}=.16
\end{aligned}
$$

After determination of the early hierarchy of indices' importance through the Delphi technique, the hierarchy and final correlations of indices' importance were determined. To this end, first of all, each of the indices were determined and then each of the indices were compared with each of the trio-zones of Alborz. As a result, 21 counts of comparison were made to determine seven indices. The comparisons were put into two-two matrixes of indices (Table 3).

The Figure 2 shows that indices of plant and animal ecology, soil and farmland, construction, climate, topography and steepness received the first to fifth priorities respectively.

Figure 2. Comparing Weights of Indices on Macro Scale and in Three South, Central and North Alborz Zones

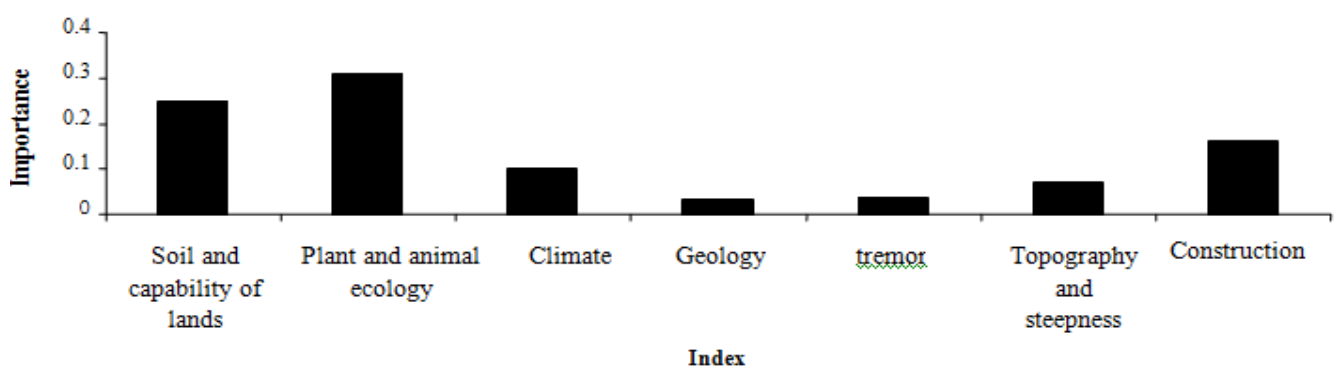

Having determined the priority of indices, all indices were tested in each of the South, Central and North Alborz zones and the priory of each of them compared to indices were determined (Table 4). 
Table 4. Determining Priority of Each of the Trio-zones of Alborz Compared to Selected Indices

\begin{tabular}{|c|c|c|c|c|}
\hline \multirow{2}{*}{\multicolumn{2}{|c|}{ Indices }} & \multicolumn{3}{|c|}{ Priority of each of the trio-zones of Alborz } \\
\hline & & North Alborz & Central Alborz & South Alborz \\
\hline \multicolumn{2}{|c|}{ Soil and capability of lands } & 1 & 3 & 2 \\
\hline Plant & \multirow{2}{*}{ Ecology } & 3 & 2 & 1 \\
\hline Animal & & 3 & 2 & 1 \\
\hline \multicolumn{2}{|l|}{ Climate } & 1 & 2 & 3 \\
\hline \multicolumn{2}{|l|}{ Geology } & 1 & 1 & 1 \\
\hline \multicolumn{2}{|l|}{ Tremor } & 1 & 2 & 2 \\
\hline \multicolumn{2}{|c|}{ Topography and steepness } & 3 & 1 & 2 \\
\hline \multicolumn{2}{|c|}{ Construction } & 3 & 1 & 1 \\
\hline
\end{tabular}

Having determined the priority of each zone in comparison to the selected indices, all indices are processed through two-by-two comparison and by formation of $3 \times 3$ matrixes in each of the three Alborz zones. At the last stage, the final score of each of the zones was determined through a mixture of the two-two comparison. Hence, multiplying the weight of each indices in the correlation of the priority of each of the zones, the score of the zone with respect to the indices is estimated. Collecting the value of all the scores, the final score for each zone is determined (Table 5 and Figure 3).

Figure 3. Comparing Degree of Importance for Each Index Compared to Each Zone of Alborz

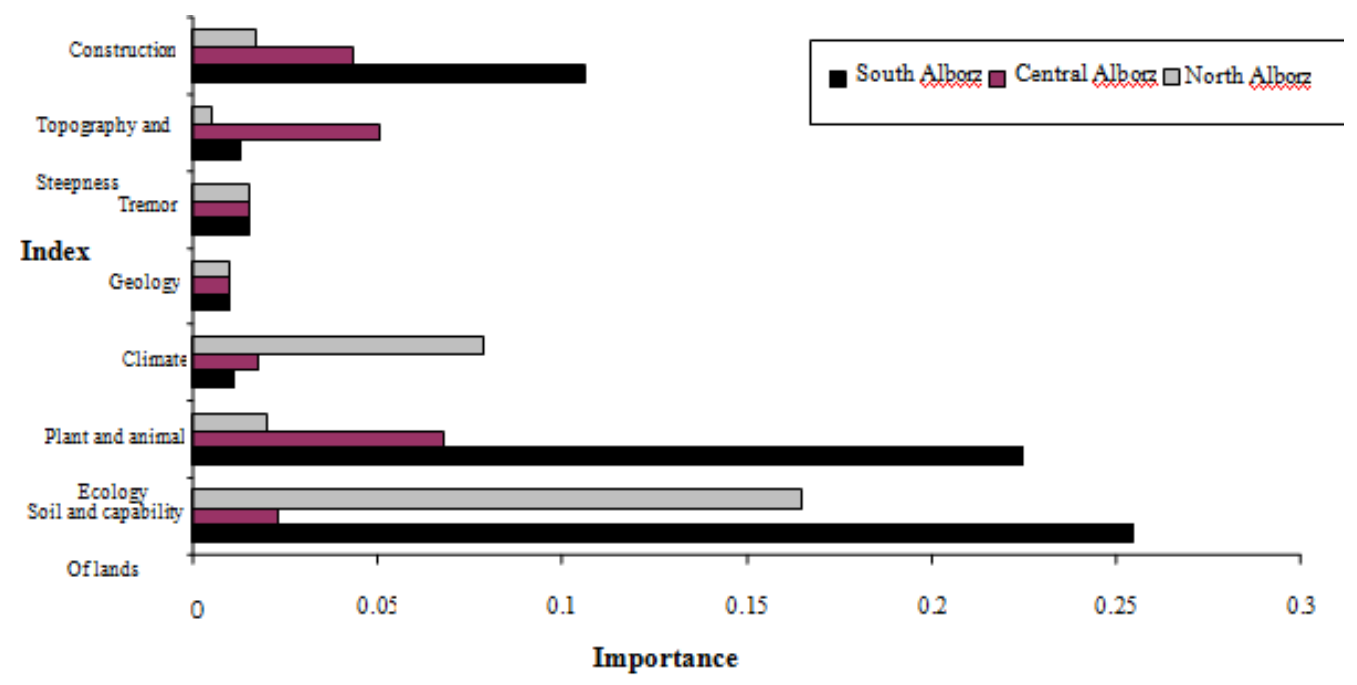


Table 5. Final Score of Each Choice With Respect to Indices and Correlation of its Priority

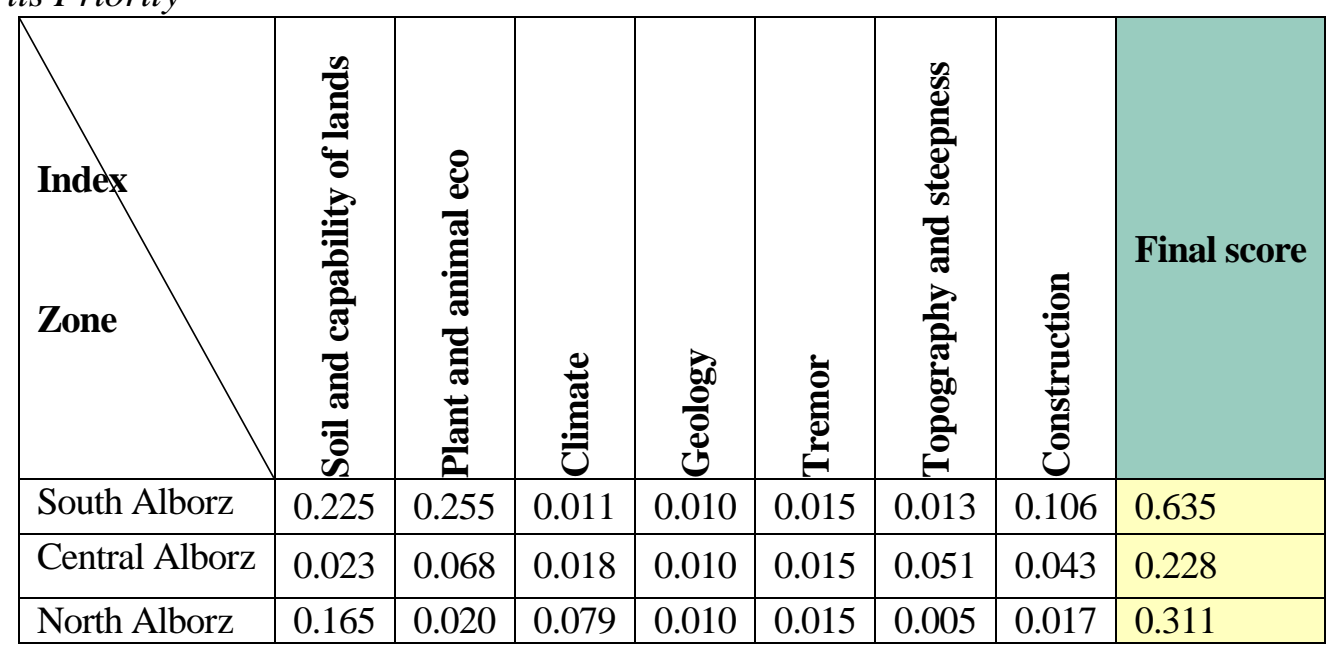

As observed, with regard to the processing and testing of indices in different fields, using the Delphi and AHP methods, the final score of the trio environmental zones of Alborz was determined using the index scores, which clarifies the degree of vulnerability. A clear result is that the South Alborz environment zone is more at environmental risk compared to the North Alborz and the North Alborz is more at risk compared to the Central Alborz. The conclusion is clearly shown in Figure 4.

Figure 4. Comparison of Importance for Each of the Trio Zones

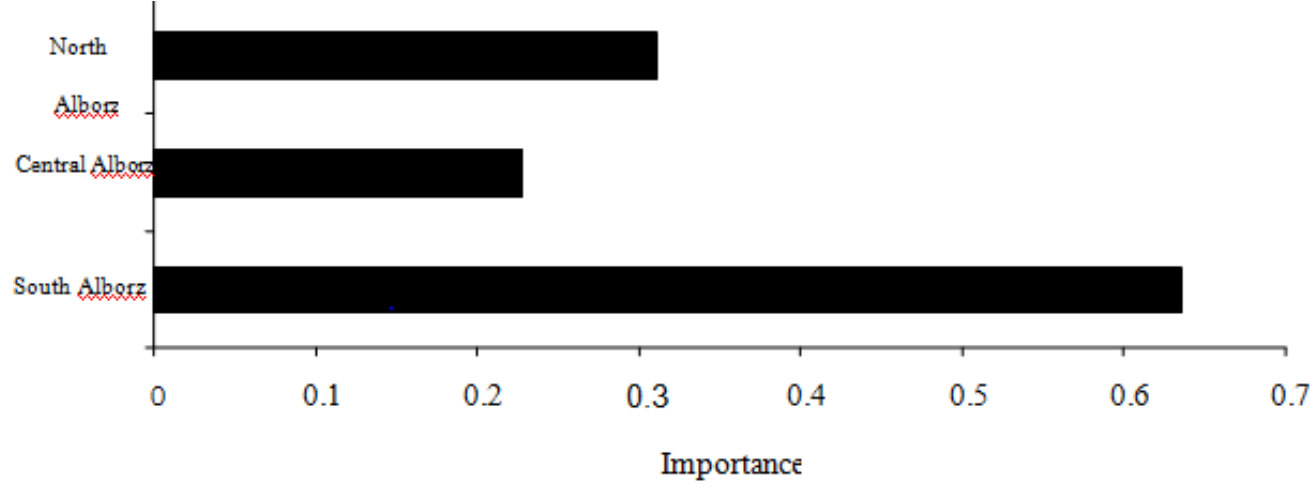

In the hierarchical analysis method there still exists a lack of coordination in judgments. Therefore, it is necessary to apply a measurement tool to minimize the degree of non-coordination in judgments. The method to investigate the inconsistencies in judgments is the coefficient of calculation, called "Inconsistency Ratio" (IR) that is gained out of dividing the "Inconsistency Index" (II) by "Random Index" (RI).

If the coefficient rate is less than 0.1 , the consistency in judgments will be acceptable; otherwise, it would be necessary to reconsider the judgments. In another words, the matrix of pair-wise comparison of indices should be re-set. The Inconsistency Ratio is gained by equation 1 . 
Equation 1. Inconsistency Ratio

$C . I=\frac{\lambda_{\max }-n}{n-1}$

The Random Index can be obtained with respect to the number of indices (Table 6).

Table 6. Random Index (RI)

\begin{tabular}{|l|l|l|l|l|l|l|l|l|l|l|l|l|l|l|}
\hline $\mathbf{n}$ & $\mathbf{2}$ & $\mathbf{3}$ & $\mathbf{4}$ & $\mathbf{5}$ & $\mathbf{6}$ & $\mathbf{7}$ & $\mathbf{8}$ & $\mathbf{9}$ & $\mathbf{1 0}$ & $\mathbf{1 1}$ & $\mathbf{1 2}$ & $\mathbf{1 3}$ & $\mathbf{1 4}$ & $\mathbf{1 5}$ \\
\hline R.I & 0.0 & 0.58 & 0.9 & 1.12 & 1.1 & 1.32 & 1.41 & 1.45 & 1.49 & 1.51 & 1.48 & 1.56 & 1.57 & 1.59 \\
\hline
\end{tabular}

In the geometric mean method, an estimated method, L is used instead of calculating the special maximum degree (Equation 2).

Equation 2. Related Wieghted

$L=\frac{1}{n}\left[\sum_{i=1}^{n}\left(A W_{i} / W_{i}\right]\right.$

In the equation 2 , AWi is a vector acquired by the multiplication of the pairwise comparison matrix of indices in the $\mathrm{Wi}$ vector (the vector of weight or coefficient of importance of indices). Surveying consistency of judgments in matrixes of pair wise comparison of indices reveals that consistency in judgments has been met (Equation 3).

Equation 3. Inconsistency Coefficient $C . R=\frac{C . I}{R . I}<0.1$

On this basis and after determining the hierarchy of the applied indices, the estimation of the degree of consistency of the pair-wise comparison matrix of indices and related judgments is done. So, the quantities of AW and L are obtained using the equation 2 and table 7 as follows:

Table 7. Aw Matrix and L Calculation

$$
\begin{gathered}
A w=\left[\begin{array}{ccccccc}
1 & 1 / 2 & 3 & 7 & 5 & 4 & 2 \\
2 & 1 & 4 & 8 & 7 & 5 & 3 \\
1 / 3 & 1 / 4 & 1 & 4 & 3 & 2 & 1 / 2 \\
1 / 7 & 1 / 8 & 1 / 4 & 1 & 1 / 2 & 1 / 3 & 1 / 5 \\
1 / 5 & 1 / 7 & 1 / 3 & 2 & 1 & 1 / 2 & 1 / 4 \\
1 / 4 & 1 / 5 & 1 / 2 & 3 & 2 & 1 & 1 / 3 \\
1 / 2 & 1 / 3 & 2 & 5 & 4 & 3 & 1
\end{array}\right] \times\left[\begin{array}{c}
0.25 \\
0.31 \\
0.1 \\
0.03 \\
0.04 \\
0.07 \\
0.16
\end{array}\right]=\left[\begin{array}{c}
1.71 \\
2.56 \\
0.72 \\
0.2 \\
0.3 \\
0.46 \\
1.1
\end{array}\right] \\
l=\frac{1}{7}\left[\frac{1.71}{0.25}+\frac{2.56}{0.31}+\frac{0.72}{0.1}+\frac{0.2}{0.03}+\frac{0.3}{0.04}+\frac{0.46}{0.07}+\frac{1.1}{0.16}\right]=7.13
\end{gathered}
$$


The degree of consistency coefficient for Tehran-North freeway is less than 0.1 (it is 0.01 ). So, it can be said that the judgments are adequately consistent and the results are converged. Similar to the first step, the degree of consistency of judgments has been surveyed in the second step and the results have been confirmed.

\section{Compilation of Strategies}

Table 8. SWOT Matrix

\begin{tabular}{|c|c|c|c|}
\hline Weaknesses (W) & Strengths (S) & \multirow{2}{*}{\multicolumn{2}{|c|}{ SWOT }} \\
\hline $\begin{array}{l}\text { - Destruction of forests and pastures North of Alborz } \\
\text { to set up freeway (W1) } \\
\text {-Fragility of plant and animal ecology South of } \\
\text { Alborz (W2) } \\
\text {-The lands with relatively high risk in Central and } \\
\text { North Alborz (W3) }\end{array}$ & $\begin{array}{l}\text {-The climatic potential favoring tourism (S1) } \\
\text {-The deterrent laws destroying environment } \\
\text { (S2) } \\
\text {-Proper soil depth North of Alborz (S3) }\end{array}$ & & \\
\hline $\begin{array}{l}\text {-Defining projects relating to increase in potential of } \\
\text { plant and animal ecology with a special emphasis on } \\
\text { South Alborz (W1-W2-O4) } \\
\text {-Improvement of method for management of habitats } \\
\text { (W1-W2-W3-O4) } \\
\text {-Expansion of watershed management activities to } \\
\text { revive environment (with more emphasis on South } \\
\text { Alborz) (W2-O4) }\end{array}$ & $\begin{array}{l}\text {-Offering tourism services (S1-O2) } \\
\text {-Giving priority to sustainable and job } \\
\text { creation tourism projects (S1-O4) } \\
\text {-Expansion and mobilization of } \\
\text { transportation facilities such as light } \\
\text { terminals, the service-welfare on-way } \\
\text { facilities (S1-S2-O1) } \\
\text {-Establishing forest and national parks in } \\
\text { areas with high tourism attraction potential } \\
\text { (S1-O1-O3) } \\
\text {-Expansion of watershed management } \\
\text { projects (with more emphasis on southern } \\
\text { part (S3-O1) } \\
\text {-Expansion of mechanized farming (S1-S3- } \\
\text { O1-O4) }\end{array}$ & $\begin{array}{l}\text {-Possibility of earning an income with } \\
\text { respect to expansion of transit role }(\mathrm{O} 1) \\
\text {-Minimizing time of transportation from } \\
\text { Mazandaran to Tehran }(\mathrm{O} 2) \\
\text {-Promotion of recreational tourism }(\mathrm{O} 3) \\
\text {-Possibilities of constructive and positive } \\
\text { developments in the social and economic } \\
\text { structures of cities lying on North Alborz } \\
\text { (O4) }\end{array}$ & 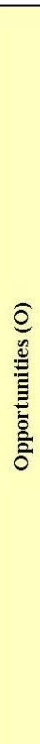 \\
\hline $\begin{array}{l}\text {-Defining integrative managerial systems to control } \\
\text { forests and pastures (W1-T1) } \\
\text {-Preparing plans to standardize recreational-service } \\
\text { facilities (W1-W2-W3-T1) } \\
\text {-Getting ensured of correspondence of environmental } \\
\text { and construction regulations with related disciplines } \\
\text {-Promoting protection standard of four } \\
\text { environmental zones (W1-T1-T3) }\end{array}$ & $\begin{array}{l}\text {-Compilation of policies to support tourism } \\
\text { industry through identification of } \\
\text { environmentally valuable regions (S1-T1) } \\
\text {-Limited and controlled definition of entrance } \\
\text { and exit convertors of freeway (S2-T2-T3) } \\
\text {-Using controlling tool to determine freeway } \\
\text { Toll Collection (S2-T1) } \\
\text {-Compiling rules and regulations on } \\
\text { geographical proximities to minimize } \\
\text { environmental pollutions (S1-S3-T1) }\end{array}$ & $\begin{array}{l}\text {-Defining environmental unfriendly } \\
\text { economic projects (T1) } \\
\text {-Building many links between freeway } \\
\text { and the residential points around (T2) } \\
\text {-Possibility for eruption of many traffic } \\
\text { problems in case of failure to find proper } \\
\text { location for activities on the margins of } \\
\text { the freeway (T3) }\end{array}$ & 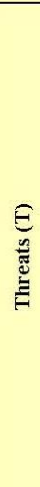 \\
\hline
\end{tabular}

In this part of the analysis, the matrix of Strengths, Weaknesses, Opportunities and Threats (SWOT) is used to compile strategies. The matrix is an important tool 
for compilation of strategies. The strategy is gained by comparing opportunities and strengths, the Strengths-Opportunities (SO). Also, through comparing strengths and threats, a Strengths-Threats strategy can be produced, as comparing Weaknesses and Opportunities there will be the Weaknesses-Opportunities (WO) strategy and the Weaknesses and Threats, there will be the Weaknesses-Threats (WT) strategies. In the matrix two factors are compared with each other in each phase and the aim is not to distinguish the best strategy, rather determining enforceable strategies (Table 8).

\section{Evaluation and Prioritizing the Strategies}

We used internal and external factors evaluation matrixes and QSPM for Evaluation and prioritizing the strategies. The matrix of internal and external factors defines and evaluates the strengths and weakness and also opportunities and threats points of the Tehran-North freeway. After arranging the factors, with consideration of the opinion of 40 experts in the Delphi team, all weights and scores have been defined. Sum of final scores for each internal and external factors have been gained by multiplication of the average of weighted factors to its scores. Here, score 1 means main weakness, score 2 defines less weakness, score 3 shows strength points of current situation and score 4 means the most strengths points for each factor.

Table 9 shows all internal factors and table 10 represents external factors of final scores. The total score for Tehran-North freeway related to internal factors is 2.76 and for external factors is 2.42 which demonstrates the average status for it.

Table 9. Internal Factors Evaluation Matrix

\begin{tabular}{|c|c|c|c|c|}
\hline \multicolumn{2}{|c|}{ Internal Factors } & Weight & Score & $\begin{array}{l}\text { Final } \\
\text { Scores }\end{array}$ \\
\hline \multirow{3}{*}{ Strengths } & The climatic potential favoring tourism & 0.2 & 1 & 0.2 \\
\hline & The deterrent laws destroying environment & 0.07 & 2 & 0.14 \\
\hline & Proper soil depth North of Alborz & 0.06 & 1 & 0.06 \\
\hline \multirow{3}{*}{ Weaknesses } & $\begin{array}{l}\text { Destruction of forests and pastures North of } \\
\text { Alborz to set up freeway }\end{array}$ & 0.25 & 3 & 0.75 \\
\hline & $\begin{array}{l}\text { Fragility of plant and animal ecology South of } \\
\text { Alborz }\end{array}$ & 0.35 & 4 & 1.4 \\
\hline & $\begin{array}{l}\text { The lands with relatively high risk in Central and } \\
\text { North Alborz }\end{array}$ & 0.07 & 3 & 0.21 \\
\hline \multicolumn{4}{|c|}{ Sum of final scores } & 2.76 \\
\hline
\end{tabular}


Table 10. External Factors Evaluation Matrix

\begin{tabular}{|l|l|c|c|c|}
\hline \multicolumn{1}{|c|}{ External Factors } & Weight & Score & $\begin{array}{c}\text { Final } \\
\text { Scores }\end{array}$ \\
\hline \multirow{5}{*}{ Opportunities } & $\begin{array}{l}\text { Possibility of earning an income with respect to } \\
\text { expansion of transit role }\end{array}$ & 0.13 & 1 & 0.13 \\
\cline { 2 - 5 } & $\begin{array}{l}\text { Minimizing time of transportation from } \\
\text { Mazandaran to Tehran }\end{array}$ & 0.08 & 2 & 0.16 \\
\cline { 2 - 5 } & Promotion of recreational tourism & 0.04 & 2 & 0.08 \\
\cline { 2 - 5 } & $\begin{array}{l}\text { Possibilities of constructive and positive } \\
\text { developments in the social and economic } \\
\text { structures of cities lying on North Alborz }\end{array}$ & 0.08 & 2 & 0.16 \\
\hline \multirow{5}{*}{ Threats } & $\begin{array}{l}\text { Defining environmental unfriendly economic } \\
\text { projects }\end{array}$ & 0.55 & 3 & 1.65 \\
\cline { 2 - 5 } & $\begin{array}{l}\text { Building many links between freeway and the } \\
\text { residential points around }\end{array}$ & 0.07 & 2 & 0.14 \\
\cline { 2 - 5 } & $\begin{array}{l}\text { Possibility for eruption of many traffic } \\
\text { problems in case of failure to find proper } \\
\text { location for activities on the margins of the } \\
\text { freeway }\end{array}$ & 0.05 & 2 & 0.1 \\
\hline Sum of final scores & & & 2.42 \\
\hline
\end{tabular}

Based on Figure 5 which shows the division of IE matrix and tables 9 and 10, the best strategies can be selected.

Figure 5. Division of IE matrix forTehran-North Freeway

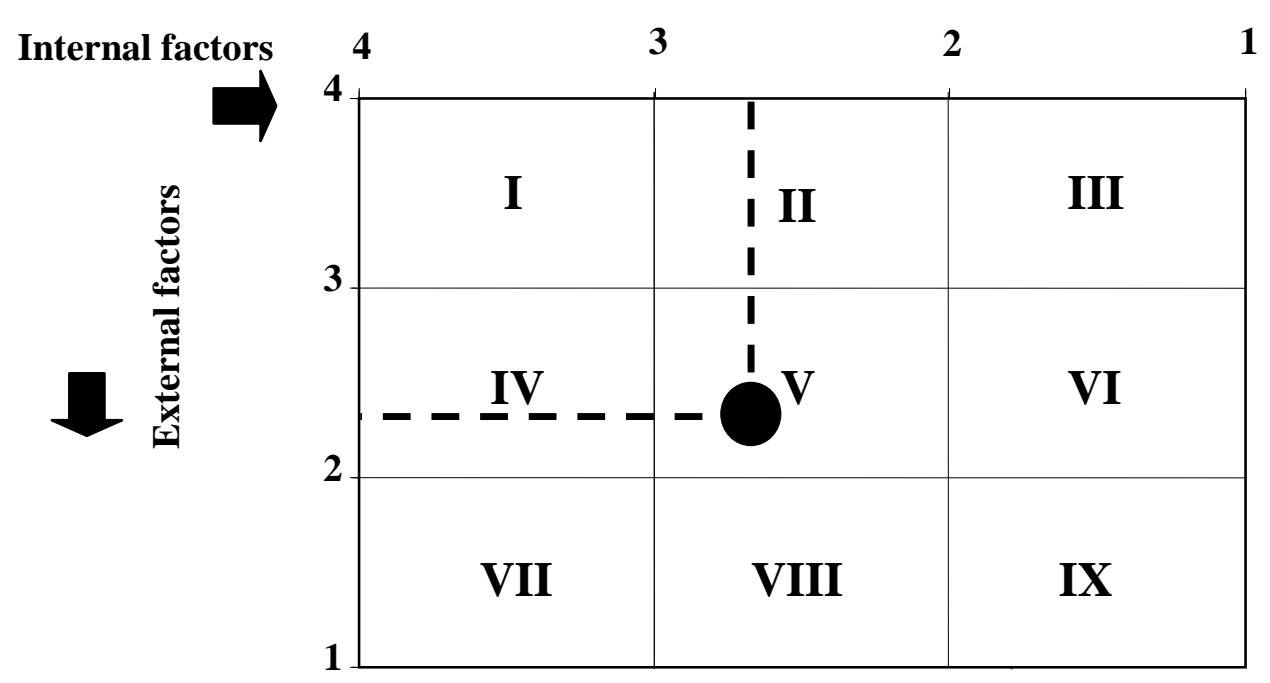

In this Figure, cells I, II and IV have been named as removal and pick up strategies and cells VI, VIII and IX mean build and growth and cells III, V and VII demonstrate maintain and watch. As Figure 4 shows, according to the final score from the evaluation of the matrix of internal and external factors $(2.76,2.42)$, IE matrix for Tehran-North freeway placed at cell V. Hence it may be inferred that, 
the Tehran-North freeway must be focused on the maintenance and watch strategies. So, after compiling strategies of Tehran-North freeway by using SWOT matrix, the W-O strategies would be evaluated and prioritized by using QSPM.

The main steps of prioritizing strategies are given in following six stages:

- Opportunities, threats, strengths and weaknesses are written in the right column of QSPM.

- Weighting each in terms of internal and external factors.

- Selected Strategies in SWOT matrix are written in the top row of QSPM.

- Attractiveness scores are determined. The attractiveness scores determine interest rate of each strategy in a series of strategies. In the scores, number one shows none-interest, number two shows some interests, number three represents reasonable interest and number four is representative of very attractive.

- Total attractiveness scores are calculated by multiplying the stage two in the stage four.

- Final scores are calculated which show the strategy is the most preferred.

At this stage the Delphi team was asked to judge and to use the QSPM for evaluating and prioritizing the three chosen strategies. At first, all weights and scores were defined. Then the sum of factors was calculated. The results are given in table 11 , respectively.

Table 11 shows the final results of the prioritized strategies and table 12 shows the rankings. The most important strategy for Tehran-North freeway is defining projects relating to increase in potential of plant and animal ecology with a special emphasis on south Alborz. 
Table 11. Tehran-North freeway QSPM

\begin{tabular}{|c|c|c|c|c|c|c|c|c|}
\hline \multirow{2}{*}{\multicolumn{2}{|c|}{ Key factors }} & \multirow{3}{*}{$\begin{array}{c}\text { Weight } \\
0.065\end{array}$} & \multicolumn{2}{|c|}{ Strategy no.1 } & \multicolumn{2}{|c|}{ Strategy no.2 } & \multicolumn{2}{|c|}{ Strategy no.3 } \\
\hline & & & Score & $\begin{array}{c}\text { Scores } \\
\text { sum }\end{array}$ & Score & $\begin{array}{c}\text { Scores } \\
\text { sum }\end{array}$ & Score & $\begin{array}{c}\text { Scores } \\
\text { sum }\end{array}$ \\
\hline \multirow{4}{*}{ Opportunities } & $\begin{array}{l}\text { Possibility of earning an income with respect to expansion of } \\
\text { transit role }\end{array}$ & & 1 & 0.065 & 1 & 0.065 & 1 & 0.065 \\
\hline & Minimizing time of transportation from Mazandaran to Tehran & 0.04 & 1 & 0.04 & 1 & 0.04 & 1 & 0.04 \\
\hline & Promotion of recreational tourism & 0.02 & 2 & 0.04 & 3 & 0.06 & 2 & 0.04 \\
\hline & $\begin{array}{l}\text { Possibilities of constructive and positive developments in the } \\
\text { social and economic structures of cities lying on North Alborz }\end{array}$ & 0.04 & 2 & 0.08 & 1 & 0.04 & 2 & 0.08 \\
\hline \multirow{3}{*}{ Threats } & Defining environmental unfriendly economic projects & 0.275 & 3 & 0.825 & 1 & 0.275 & 2 & 0.55 \\
\hline & $\begin{array}{l}\text { Building many links between highway and the residential points } \\
\text { around }\end{array}$ & 0.035 & 2 & 0.07 & 1 & 0.035 & 2 & 0.07 \\
\hline & $\begin{array}{l}\text { Possibility for eruption of many traffic problems in case of failure } \\
\text { to find proper location for activities on the margins of the } \\
\text { highway }\end{array}$ & 0.025 & 2 & 0.05 & 1 & 0.025 & 2 & 0.05 \\
\hline \multirow{3}{*}{ Strengths } & The climatic potential favoring tourism & 0.1 & 3 & 0.3 & 2 & 0.2 & 2 & 0.2 \\
\hline & The deterrent laws destroying environment & 0.035 & 2 & 0.07 & 2 & 0.07 & 2 & 0.07 \\
\hline & Proper soil depth North of Alborz & 0.03 & 1 & 0.03 & 1 & 0.03 & 1 & 0.03 \\
\hline \multirow{3}{*}{ Weakness } & $\begin{array}{l}\text { Destruction of forests and pastures North of Alborz to set up } \\
\text { highway }\end{array}$ & 0.125 & 3 & 0.375 & 3 & 0.375 & 3 & 0.375 \\
\hline & Fragility of plant and animal ecology South of Alborz & 0.175 & 3 & 0.525 & 2 & 0.35 & 4 & 0.7 \\
\hline & The lands with relatively high risk in Central and Northern Alborz & 0.035 & 1 & 0.035 & 1 & 0.035 & 3 & 0.105 \\
\hline \multicolumn{3}{|l|}{ Sum of factors } & & 2.505 & & 1.600 & & 2.375 \\
\hline
\end{tabular}


Table 12. Straegies Ranking

\begin{tabular}{|c|l|}
\hline Rank & \multicolumn{1}{|c|}{ Strategies } \\
\hline 1 & $\begin{array}{l}\text { Defining projects relating to increase in potential of plant and animal ecology with } \\
\text { a special emphasis on south Alborz }\end{array}$ \\
\hline 3 & Improvement of method for management of habitats \\
\hline 2 & $\begin{array}{l}\text { Expansion of watershed management activities to revive environment (with more } \\
\text { emphasis on south Alborz) }\end{array}$ \\
\hline
\end{tabular}

\section{Conclusion}

This paper presents an integrated model as a proposed methodology to evaluate vulnerability of trio zones of Alborz Mountains based on Tehran-North freeway construction and also compiles and prioritizes strategies for Tehran-North freeway strategic planning. The proposed methodology has potential to be utilized in other types of urban and regional strategic planning.

In this paper, the AHP model was used for the evaluation of trio Alborz zones vulnerability. It became clear that the south Alborz zone is distinguished as one of the most fragile environmental zones. Thus, it should be given the first priority in terms of management and control of the natural resources. Moreover, the north Alborz should be given the second priority in terms of protecting forests and coastal lands from destruction. Managerial mechanisms should be used to control coastal and forest lands. Eventually, the central Alborz zone should be given the priority to protect the wildlife and animal ecology. As a general finding, the Delphi team considered internal factors to be more important than external factors in making their decisions related to Tehran-North freeway.

The best strategies for monitoring and reducing impacts of Tehran-North freeway construction were compiled by SWOT matrix and finally these strategies were prioritized by QSPM model. Identifying the strengths, weaknesses, opportunities and threats by the SWOT matrix would help decision makers have more complete insight on the issue under assessment. It will also help in compiling strategies in the following phases with more care. The outcome of the article would help planners and managers be more capable of implementation and managing impacts of Tehran-North freeway construction and empower them to multidimensional decision making on economic, environmental and transportation domains.

\section{References}

Albayrak E, Erensal YC (2004) Using analytic hierarchy process (AHP) to improve human performance. An application of multiple criteria decision-making problem. Journal of Intelligent Manufacturing 15: 491-503.

Amin SH, Razmi J, Zhang G (2011) Supplier selection and order allocation based on fuzzy SWOT analysis and fuzzy linear programming. Expert Systems with Applications 38: 334-342.

Chang HH, Huang WC (2006) Application of a quantification SWOT analytical method. 
Mathematica land Computer Modeling 43:158-169.

Dalkey N (1969) An experimental study of group opinion: The Delphi method. Futures 1(5): 408-426.

David FR (2001) Strategic management. Prentice Hall: Upper Saddle River.

David FR (1983) Concepts of Strategic Management, $4^{\text {th }}$ ed. New York, NY: Macmillan.

Handfield R, Walton SV, Sroufe R, Melnyk SA (2002) Applying environmental criteria to supplier assessment: A study in the application of the Analytical Hierarchy Process. European Journal of Operational Research 141: 70-87.

Hasson F, Keeney S, McKenna H (2000) Research guidelines for the Delphi survey technique. Journal of Advanced Nursing 32: 1008-15.

Hill CH, Jones G (1995) Strategic management theory. An integrated approach. Boston: Houghton Mifflin.

Houben G, Lenie K, Vanhoof K (1999) A knowledge-based SWOT-analysis system as an instrument for strategic planning in small and medium sized enterprises. Decision Support Systems 26: 125-135.

Kandakoglu A, Celik M, Akgun I (2009) A multi-methodological approach for shipping registry selection in maritime transportation industry. Mathematical and Computer Modeling 49: 586-597.

Kazaz A, Ulubeyli S (2009) Strategic management practices in Turkish construction firms. Journal of Management in Engineerin, 25: 185-194.

Kurttila M, Pesonen J, Kangas M, Kajanus M (2000) Utilizing the analytic hierarchy process (AHP) in SWOT analysis hybrid method and its application to a forestcertification case. Forest Policy and Economics 1: 41-52.

Lee S, Walsh P, Vanhoof K (2011) SWOT and AHP hybrid model for sport marketing outsourcing using a case of intercollegiate sport. Sport Management Review 14: 361369.

Mintzberg H (1994) The rise and fall of strategic planning. New York: Prentice Hall.

Podvezko V, Mitkus S, Trinkuniene E (2010) Complex evaluation of contracts for construction. Journal of Civil Engineering and Management 16: 287-297.

Porter M (1987, May) The state of strategic thinking. Economist 23: 1987.

Price ADF, Newson E (2003). Strategic management: consideration of paradoxes, processes, and associated concepts as applied to construction. Journal of Management in Engineering 19: 183-192.

Road and Urbanization Ministry (2014) Strategic plan of Tehran-North freeway. Iran.

Saaty TL (1980) The analytical hierarchy process. Newyork: M. Graw Hill.

Sharifzadegan MH, Malekpour Asl B, Stough R (2015) Regional endogenous development based on conceptualizing a regional productivity model for application in Iran. Applied Spatial Analysis and Policy 10(1): 43-75.

Taleai M, Mansourian M, Sharifi A (2009) Surveying general prospects and challenges of GIS implementation in developing countries: a SWOT-AHP approach. Journal of Geographical System 11: 291-310. 
